\title{
An XO/X Ring X Chromosome Mosaicism in an Individual with Normal Secondary Sexual Development
}

\author{
AUDREY M. BISHOP, C. E. BLANK, K. SIMPSON, and C. J. DEWHURST
}

From the Centre for Human Genetics, United Sheffield Hospitals, the Department of Genetics, and the Department of Obstetrics and Gynaecology, University of Sheffield, and the Royal Infirmary, Leicester

Ring chromosomes in man, in association with congenital abnormalities, have been reported involving a chromosome in the 17-18 group (Genest, Leclerc, and Auger, 1963; Gropp, Jussen, and Ofteringer, 1964; Lucas, Kemp, Ellis, and Marshall, 1963; Wang, Melnyk, McDonald, Uchida, Carr, and Goldberg, 1962), a chromosome in the X-6-I 2 group which is probably not an $X$ (Turner, 1963), a member of the 13-I 5 group (Smith-White, Peacock, Turner, and Den Dulk, 1963), a No. I chromosome (Gordon and Cooke, 1964), and on five occasions an $\mathrm{X}$ chromosome (Bain, Gauld, and Farquhar, I965; Hustinx and Stoelinga, 1964; Lindsten and Tillenger, 1962; Lüers, Struck, and Nevinny-Stickel, 1963; Pfeiffer and Büchner, 1964). We report the findings in a further patient with a presumptive ring $\mathrm{X}$ chromosome.

\section{Case Report}

The patient was referred for paediatric opinion because at the age of 13 years she was still only $125 \mathrm{~cm}$. tall. However, her secondary sexual development was normal and she first menstruated shortly after her $13^{\text {th }}$ birthday. After a few months without periods she began to menstruate regularly. Two buccal smears taken at this time failed to show sex chromatin, and it seemed possible, that despite her normal secondary sexual development and regular menstruation, she might have a sex chromosome abnormality. She was referred for detailed chromosomal study.
Sex Chromatin and Chromosome Analysis. Of the 120 nuclei examined in buccal smear preparations, $6(5 \%)$ had a single, normal-sized, sex chromatin body. Sex chromatin bodies are found by this observer (A.M.B.) with a frequency of $25-60 \%$ in normal females and are not observed in normal males. Further sex chromatin preparations were obtained from skin culture. These latter preparations were made in parallel with a control culture from a normal female. The preparations derived from the normal female were sex chromatin positive, but of 300 cells examined in the skin culture derived from the propositus, not one showed a sex chromatin body. A blood smear preparation was analysed and 3 drumsticks (0.6\%) were found in 500 polymorphonuclear leucocytes. Mittwoch (I964) in an investigation of 12 normal females found a mean drumstick count of $3.66 \%$.

Chromosome counts showed two cell types with 45 and 46 chromosomes, in three independent blood cultures and a skin culture.

Analysis demonstrated $\mathrm{XO}$ and $\mathrm{XO}$ plus a ring chromosome karyotypes (Table I). The ring chromosome was of variable size (Fig. I).

The pattern of DNA synthesis was studied in the third blood culture, labelled for 4 hours with tritiated thymidine (Bishop and Bishop, 1963). In all, 300 cells were examined: 4I had a count of 46 chromosomes. I4 of these 4I were labelled, and 8 showed a concentration of labelling over the ring chromosome with slight labelling over the other members of the complement (Fig. 2). These 8 cells were presumably at the end of DNA synthesis when labelling occurred. It was, therefore, assumed that the ring chromosome was a structurally abnormal, late-labelling, $\mathrm{X}$ chromosome. A

Received May 14, 1965. 

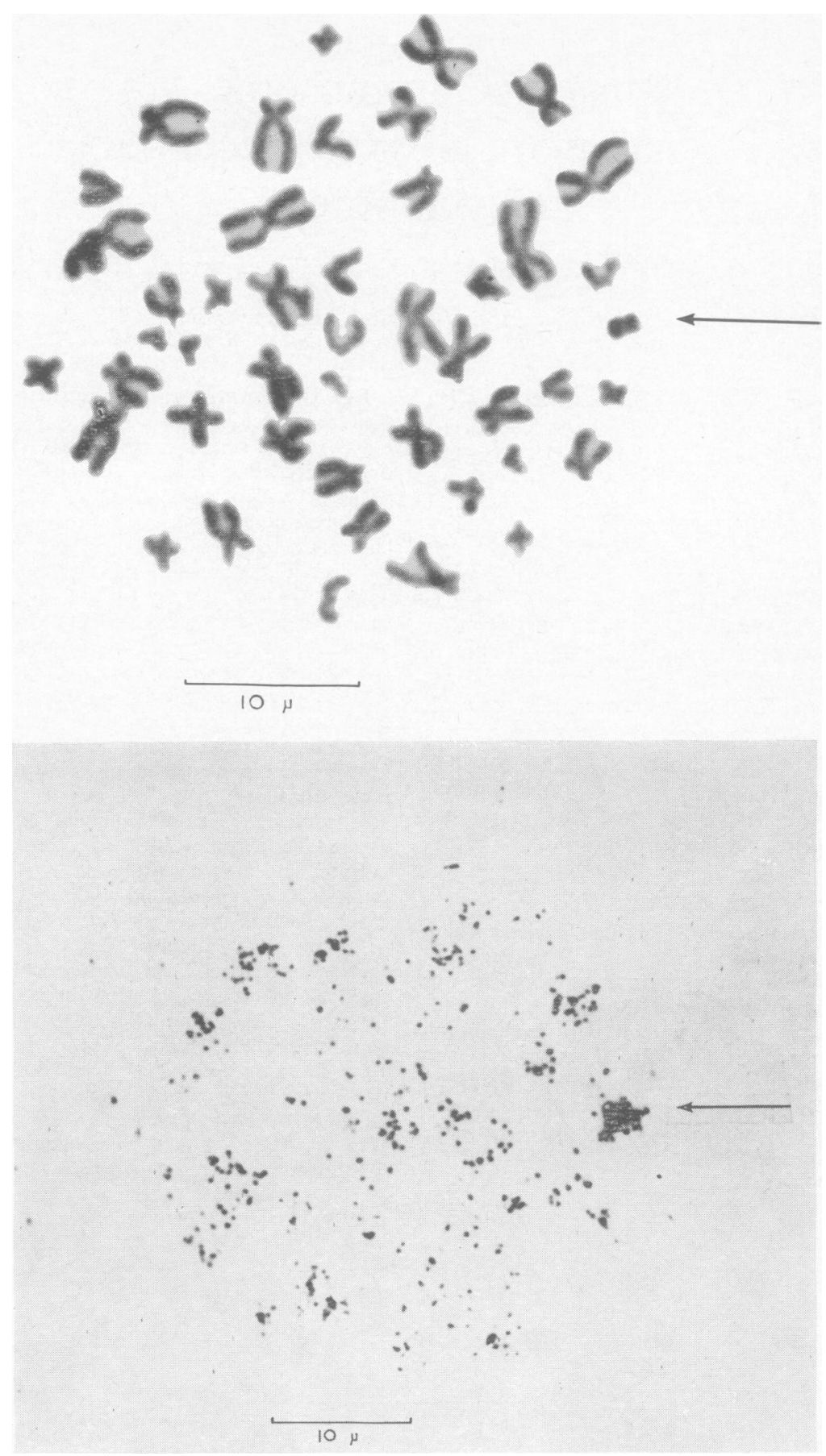

Fig. 2. A cell, labelled at the end of DNA synthesis, with its corresponding autoradiograph, showing late labelling of the ring. 
TABLE I

\begin{tabular}{|c|c|c|c|c|c|c|c|}
\hline \multirow{2}{*}{\multicolumn{2}{|c|}{ Tissue }} & \multicolumn{6}{|c|}{ Chromosome Counts } \\
\hline & & \multicolumn{2}{|c|}{45} & \multicolumn{2}{|c|}{46} & \multicolumn{2}{|c|}{47} \\
\hline & & Counted & Analysed* & Counted & Analysed $†$ & Counted & Analysed‡ \\
\hline $\begin{array}{l}\text { Blood culture } \\
\text { Skin culture }\end{array}$ & $\begin{array}{l}1 \\
2 \\
3\end{array}$ & $\begin{array}{r}27 \\
69 \\
255 \\
23\end{array}$ & $\begin{array}{l}4 \\
0 \\
4 \\
4\end{array}$ & $\begin{array}{r}3 \\
11 \\
41 \\
3\end{array}$ & $\begin{array}{r}3 \\
\text { II } \\
4 I \\
3\end{array}$ & $\begin{array}{l}0 \\
0 \\
4 \\
0\end{array}$ & $\begin{array}{l}0 \\
0 \\
4 \\
0\end{array}$ \\
\hline
\end{tabular}

* $44 \mathrm{~A}+\mathrm{XO}$

+56 cells were $44 \mathrm{~A}+\mathrm{X}$ ring $\mathrm{X}$. One cell contained $44 \mathrm{~A}+\mathrm{X}+$ acentric fragment and another $44 \mathrm{~A}+\mathrm{X}$ dicentric ring $\mathrm{X}$.

$\$ 44 A+X$ ring $X$ ring $X$.

late-labelling member of the X-6-I2 group wàs not seen in the cells with a count of 45 chromosomes.

It was concluded that the patient was a $44+\mathrm{XO} / 44+$ $\mathrm{X}$ ring $\mathrm{X}$ mosaic.

\section{Discussion}

A comparison may be made between this patient and the 5 others in whom it was believed a ring $\mathrm{X}$ chromosome had been observed (Table II). Although each patient had one or more of the clinical abnormalities characteristic of gonadal dysgenesis (Turner's syndrome), the only abnormal clinical feature common to them all was short stature. Our patient bears some resemblance to Case 3 in that each had normal secondary sexual development and regular periods in association with dwarfism.

A cytological comparison (Table II) shows that all were mosaics of $\mathrm{XO}$ and $\mathrm{X}$ ring $\mathrm{X}\left(\mathrm{XX}_{\mathrm{R}}\right)$ cells. The frequency of $\mathrm{XO}$ cell lines and the size of the ring chromosome in cultures established from these patients were variable and plainly cannot be related to the clinical findings.

Evidence on the origin of these ring chromosomes was obtained from autoradiography and sex chromatin analysis. Late replication, characteristic of heteropycnotic $\mathrm{X}$ chromosomes in excess of one, whether structurally normal or abnormal (Gilbert, Muldal, Lajtha, and Rowley, 1962; Muldal, Gilbert, Lajtha, Lindsten, Rowley, and Fraccaro, 1963), was observed for the ring chromosomes studied in Case 4 (Rowley, Muldal, Lindsten, and Gilbert, 1964) and in our patient. It was, therefore, apparent that in these two the ring was an X chromosome. Cases 2, 3, and 5 were sex chromatin positive, though far fewer cells than normal had a sex chromatin body. It is reasonable to assume that the chromosome abnormalities observed in these latter cases also involved the sex chromosome complement and that the ring chromosomes observed were $\mathrm{X}$ chromosomes. However, the patient described by Pfeiffer and
Büchner (1964) wàs sex chromatin negative. Furthermore, the ring chromosome did not appear to be differentially labelled. Pfeiffer and Büchner suggested that the interstitial, late-replicating (Atkins and Gustavson, 1964; Gianelli, 1963) parts of the $\mathrm{X}$ chromosome were absent from the ring chromosome observed in their patient. It does, however, seem possible that their ring chromosome was not an $\mathrm{X}$ chromosome but a $\mathrm{Y}$ chromosome. The $\mathrm{Xg}^{\mathrm{a}}$ blood group findings did not clearly distinguish between these alternatives (Nijenhuis and Gemser-Runia, 1964).

Chromosome analysis on a skin culture preparation derived from our patient showed the presence of $\mathrm{XX}_{\mathrm{R}}$ cells with a frequency of approximately II \%, yet not one of the 300 interphase nuclei examined for sex chromatin showed a well-defined heteropycnotic body adjacent to the nuclear membrane. Sex chromatin bodies were observed in skin culture preparations by Hustinx and Stoelinga (Case 3) when the frequency of $\mathbf{X X}_{\mathbf{R}}$ cells was $\mathrm{I} \%$ and by Lindsten and Tillinger (Case 4) when the frequency of $\mathrm{XX}_{R}$ cells was 10\% (Table II). However, the ring $\mathrm{X}$ chromosome in our patient was smaller than the ring chromosomes observed by these authors. It might be that this ring $\mathrm{X}$ chromosome was too small, at least in skin culture preparations, to be visible as a distinguishable heteropycnotic body. Alternatively, it may have been that the frequency of $\mathrm{XX}_{\mathrm{R}}$ cells in preparations studied for chromosome analysis was different from that studied for sex chromatin analysis. Furthermore, sex chromatin preparations were made several weeks later than the chromosome preparations, and the $\mathrm{XX}_{\mathrm{R}}$ cell line may have been lost due to well-known instability of the ring chromosomes. The observations that we have made on the variable size of the ring and the presence of two rings in some cells are evidence of this instability.

It was concluded that breakage of an $\mathrm{X}$ chromosome, during meiosis or early cleavage, led to loss 
TABLE II

\begin{tabular}{|c|c|c|c|c|c|c|c|}
\hline \multirow{3}{*}{ Reference } & \multirow{3}{*}{ Clinical Description } & \multicolumn{5}{|c|}{ Cytology } & \multirow{3}{*}{$\begin{array}{c}\text { Labelling of Rin } \\
\text { with Tritiated } \\
\text { Thymidine }\end{array}$} \\
\hline & & \multicolumn{2}{|c|}{ Chromosome Analysis } & \multirow{2}{*}{$\begin{array}{l}\text { Size of Ring } \\
\text { Circumference } \\
\text { of } \mathrm{X}_{\mathrm{R}} / \text { Length } \\
\text { of Normal X }\end{array}$} & \multicolumn{2}{|c|}{$\begin{array}{l}\text { Sex Chromatin } \\
\text { Analysis }\end{array}$} & \\
\hline & & Blood culture & Skin culture & & $\begin{array}{c}\text { Buccal } \\
\text { Mucosa }\end{array}$ & $\begin{array}{l}\text { Skin } \\
\text { Culture }\end{array}$ & \\
\hline $\begin{array}{l}\text { Case I } \\
\text { Pfeiffer and } \\
\text { Büchner } \\
(1964)\end{array}$ & $\begin{array}{l}\text { 2-year-old girl; } \\
\text { 'typical features } \\
\text { of Turner's } \\
\text { syndrome'; no } \\
\text { laparotomy }\end{array}$ & $\begin{array}{l}40 \% \text { XO cells } \\
60 \% \mathrm{XX}_{\mathrm{R}} \text { cells }\end{array}$ & & $\begin{array}{l}\text { Approx. three- } \\
\text { quarters }\end{array}$ & Negative & & $\begin{array}{l}\text { Ring X not late- } \\
\text { labelling; } \\
\text { corresponds witl } \\
\text { observations of } \\
\text { unlabelled } \\
\text { pericentric and } \\
\text { terminal regions } \\
\text { of normal X }\end{array}$ \\
\hline $\begin{array}{l}\text { Case } 2 \\
\text { Lüers et al. } \\
\text { (1963) }\end{array}$ & $\begin{array}{l}\text { 20-year-old woman, } \\
\text { I } 40 \mathrm{~cm} \text {. height; } \\
\text { no menses; } \\
\text { infantile } \\
\text { secondary sex } \\
\text { characters; no } \\
\text { laparotomy }\end{array}$ & $\begin{array}{l}73 \% \text { XO cells } \\
17 \% \mathrm{XX} \text { cells } \\
6 \% \mathrm{XX}_{\mathrm{R}} \text { cells }\end{array}$ & & & $9 \%$ & & 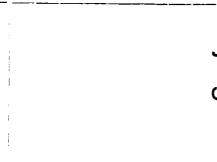 \\
\hline $\begin{array}{l}\text { Case } 3 \\
\text { Hustinx and } \\
\text { Stoelinga } \\
(1964)\end{array}$ & $\begin{array}{l}\text { I s-year-old girl, } \\
\text { I } 37 \mathrm{~cm} \text {. height; } \\
\text { menstruation } \\
\text { normal; } \\
\text { secondary sex } \\
\text { characters } \\
\text { normal; webbed } \\
\text { neck; small } \\
\text { mandible and } \\
\text { syndactyly; no } \\
\text { laparotomy }\end{array}$ & $\begin{array}{l}88 \% \text { XO cells } \\
12 \% \mathrm{XX}_{\mathrm{R}} \text { cells }\end{array}$ & $\begin{array}{l}99 \% \mathrm{XO} \text { cells } \\
1 \% \mathrm{XX}_{\mathrm{R}} \text { cells }\end{array}$ & Approx. I.o & $5 \%$ & $9 \cdot 6 \%$ & : \\
\hline $\begin{array}{l}\text { Case } 4 \\
\text { Lindsten and } \\
\text { Tillenger } \\
(\mathrm{I962)}\end{array}$ & $\begin{array}{l}\text { 22-year-old woman, } \\
\text { I } 43 \mathrm{~cm} \text {. height; } \\
\text { menstruation } \\
\text { regular at first } \\
\text { but later } \\
\text { oligomenorrhoea; } \\
\text { well-developed } \\
\text { secondary sex } \\
\text { characters; slight } \\
\text { cubitus valgus; } \\
\text { scarcity of } \\
\text { primordial } \\
\text { follicles and only } \\
2 \text { graafian follicles }\end{array}$ & $\begin{array}{l}63 \% \text { XO cells } \\
35 \% \mathrm{XX}_{\mathrm{R}} \text { cells }\end{array}$ & $\begin{array}{l}90 \% \text { XO cells } \\
10 \% \\
X X_{\mathrm{R}} \text { cells }\end{array}$ & $0.6-1 \cdot 0$ & Negative & Positive & $\begin{array}{l}\text { Ring } \mathrm{X} \text { the only } \\
\text { late-labelling } \mathrm{X}\end{array}$ \\
\hline $\begin{array}{c}\text { Case } 5 \\
\text { Bain et al. } \\
(1965)\end{array}$ & $\begin{array}{l}\text { 5-year-old girl, } \\
92.5 \mathrm{~cm} \text {. height }\end{array}$ & $\begin{array}{l}33 \% \text { XO cells } \\
63 \% \mathrm{XX}_{\mathrm{R}} \text { cells }\end{array}$ & & Variable & $10 \%$ & & \\
\hline $\begin{array}{c}\text { Our case } \\
(1965)\end{array}$ & $\begin{array}{l}\text { 13-year-old girl, } \\
\text { 125 cm. height; } \\
\text { menstruation } \\
\text { normal; } \\
\text { secondary sex } \\
\text { characters } \\
\text { normal; no } \\
\text { laparotomy }\end{array}$ & $\begin{array}{l}86 \% \text { XO cells } \\
14 \% \mathrm{XX}_{\mathrm{R}} \text { cells }\end{array}$ & $\begin{array}{l}89 \% \text { XO cells } \\
\text { I } 1 \% \text { XX cells }\end{array}$ & $\begin{array}{l}\text { Variable up to } \\
\text { three-quarters }\end{array}$ & $5 \%$ & Negative & $\begin{array}{l}\text { Ring } X \text { the only } \\
\text { late-labelling } \mathbf{X}\end{array}$ \\
\hline
\end{tabular}

* Culture of biopsy specimen of ovary yielded roo\% XO cells. Culture of lymph node yielded $90 \% \mathrm{XO}$ and $10 \% \mathrm{XX}$.

t Estimated from authors' data.

of chromosomal material and ring formation giving rise to the $\mathrm{XX}_{\mathrm{R}}$ cell line. It is probable that subsequent loss of the unstable ring $\mathrm{X}$ chromosome gave rise to the $\mathrm{XO}$ cell line.

\section{Summary}

A 13-year-old girl with $\mathrm{XO} / \mathrm{X}$ ring $\mathrm{X}$ mosaicism is reported. The only clinical abnormality observed was dwarfism. The investigations on the sex chromatin and chromosomes in buccal smear, skin, and blood and autoradiographic studies are dis cussed. The cytological and clinical data are compared with those in previously described patients.

We are grateful to Dr. Ursula Mittwoch for the drumstick analysis of the blood smear.

\section{REFERENCES}

Atkins, L., and Gustavson, K. H. (1964). The pattern of DNa synthesis in human chromosomes in cells with an XXY s. chromosome constitution. Hereditas (Lund), 51, 135. 
Bain, A. D., Gauld, I. K., and Farquhar, J. W. (1965). A ring $\mathrm{X}$ chromosome in dwarfism. Lancet, $\mathbf{1}, 820$.

Bishop, A., and Bishop, O. N. (1963). Analysis of tritium-labelled human chromosomes and sex chromatin. Nature (Lond.), 199, 930.

Genest, P., Leclerc, R., and Auger, C. (1963). Ring chromosome and partial translocation in the same cell. Lancet, $\mathbf{1}, 1426$.

Gianelli, F. (1963). The pattern of X-chromosome deoxyribonucleic acid synthesis in two women with abnormal sex-chromosome complements. ibid., 1, 863.

Gilbert, C. W., Muldal, S., Laitha, L. G., and Rowley, J. (1962). Time-sequence of human chromosome duplication. Nature (Lond.), 195, 869.

Gordon, R. R., and Cooke, P. (1964). Ring-I chromosome and microcephalic dwarfism. Lancet, 2, I212.

Gropp, A., Jussen, A., and Ofteringer, K. (1964). Multiple congenital anomalies associated with a partially ring-shaped chromosome probably derived from chromosome No. 18 in man. Nature (Lond.), 202, 829.

Hustinx, T. W., and Stoelinga, G. B. (1964). A ring-X-chromosome in part of the somatic cells of a patient with some characteristics of the Turner syndrome. Genetica, 35, I.

Lindsten, J., and Tillenger, K.-G. (I962). Self-perpetuating ring chromosome in a patient with gonadal dysgenesis. Lancet, $\mathbf{I}, 593$. Lucas, M., Kemp, N. H., Ellis, J. R., and Marshall, R. (I963). A small autosomal ring chromosome in a female infant with congenital malformations. Ann. hum. Genet., $27,189$.

Lüers, T., Struck, E., and Nevinny-Stickel, J. (I963). Selfperpetuating ring chromosome in gonadal dysgenesis. Lancet, 2, 887.

Mittwoch, U (1964). Frequency of drumsticks in normal women and patients with chromosomal abnormalities. Nature (Lond.), 201, 317.

Muldal, S., Gilbert, C. W., Laitha, L. G., Lindsten, J., Rowley, J., and Fraccaro, M. (1963). Tritiated thymidine incorporation in an isochromosome for the long arm of the $\mathrm{X}$ chromosome in man. Lancet, I, 861.

Nijenhuis, L. E., and Gemser-Runia, J. (1964). Xga investigations of the family of a child with a ring $\mathrm{X}$ chromosome. Nature (Lond.), 204, 792.

Pfeiffer, R. A., and Büchner, T. (1964). Absence of late replication of a human X-ring chromosome. ibid., 204, 804.

Rowley, J., Muldal, S., Lindsten, J., and Gilbert, C. W. (I964). $\mathrm{H}^{3}$-Thymidine uptake by a ring $\mathrm{X}$ chromosome in a human female. Proc. nat. Acad. Sci. (Wash.), 51, 779.

Smith-White, S., Peacock, W. J., Turner, B., and Den Dulk, G. M. (1963). A ring chromosome in man. Nature (Lond.), 197, 102. Turner, B. (1963). Cytogenetic studies in mental retardation. Proc. Aust. Ass. Neurol., I, 4I.

Wang, H.-C., Melnyk, J., McDonald, L. T., Uchida, I. A., Carr, D. H., and Goldberg, B. (1962). Ring chromosomes in human beings. Nature (Lond.), 195, 733. 